\title{
THE DEVELOPMENT AND PERFORMANCE OF LISTED PROPERTY TRUST FUTURES
}

\author{
GRAEME NEWELL and TAN YEN KENG \\ University of Western Sydney
}

\begin{abstract}
Listed property trust futures were established on the Australian Stock Exchange (ASX) in August 2002; this being a world first. These property trust futures have been the most actively supported of the range of futures products on the ASX. Using a number of scenarios, property trust futures are shown to be an effective risk management tool for institutional investors for hedging their listed property trust exposure.
\end{abstract}

Keywords: LPTs, LPT futures, risk management, hedging, investment dynamics, performance analysis, scenario analysis

\section{INTRODUCTION}

Listed property trusts (LPTs) have been a successful indirect property investment vehicle in Australia (Property Investment Research, 2002). At November 2003, the LPT sector had total assets of $\$ 80$ billion (Property Investment Research, 2003) and accounted for over $\$ 48$ billion in market capitalisation, being the third largest stockmarket sector and representing over $8 \%$ of total Australian stockmarket capitalisation (UBS Warburg, 2003). Currently, LPTs account for approximately $8 \%$ of institutional asset allocations and have approximately $70 \%$ of institutional ownership. LPTs also have a high level of liquidity, with an annual LPT turnover of over $\$ 40$ billion in 2003 (UBS Warburg, 2003).

LPT and stockmarket performance in Australia are correlated $(r=.66$ over 19852003) (Property Council of Australia, 2003) and it has been shown that there is no long-term market integration between LPTs and the stockmarket (Wilson and Okunev, 1996, 1999; Wilson et al, 1998). This evidence of market segmentation suggests that there are diversification benefits from including LPTs in an investment portfolio, particularly in conditions of increased stockmarket volatility (Newell and Acheampong, 2001). Further evidence of the investment stature of LPTs is shown in Table 1, with the investment performance of LPTs compared to the other major asset classes (Property Council of Australia, 2003). Over each of the $1,3,5$ and 10-year holding periods, LPTs were the best-performed asset class. This reflects the significant growth and maturity of the LPT sector in the last ten years. 
Table 1: LPT performance analysis: June 2003*

\begin{tabular}{lcrrr}
\hline \multirow{2}{*}{ Asset class } & \multicolumn{5}{c}{ Average annual returns } \\
& $\mathbf{1 Y}$ & $\mathbf{3 Y}$ & $\mathbf{5 Y}$ & $\mathbf{1 0 Y}$ \\
\hline LPTs & $12.2 \%(1)$ & $13.8 \%(1)$ & $11.5 \%(1)$ & $11.6 \%(1)$ \\
Shares & $-1.1 \%(4)$ & $0.9 \%(4)$ & $6.2 \%(3)$ & $9.7 \%(3)$ \\
Bonds & $8.5 \%(3)$ & $6.7 \%(3)$ & $5.9 \%(4)$ & $7.3 \%(4)$ \\
Property & $10.8 \%(2)$ & $10.5 \%(2)$ & $10.5 \%(2)$ & $9.8 \%(2)$ \\
\hline
\end{tabular}

*: ranks per time period are given in brackets.

Source: PCA (2003)

In August 2002, the Australian Stock Exchange (ASX) established a listed property trust futures market; this being a world first for this property finance sector. This allowed Australian fund managers to use LPT futures contracts to facilitate tactical asset allocation to protect the value of their LPT portfolios by managing their cash flows more effectively, allowing hedging of LPT exposures quickly, and reducing holding and transaction costs.

While the general context of LPT futures has been given (Montgomery, 2002), no detailed analysis of the development and performance of LPT futures has yet been carried out. As such, this paper will examine the development and performance of ASX LPT futures over August 2002 - December 2003; particularly focusing on the use of LPT futures as an effective risk management strategy for institutional LPT portfolios.

\section{PROPERTY FUTURES}

Futures markets are well established for commodities futures, financial/interest rate futures and stock index futures. The benefits provided by futures contracts include facilitating tactical asset allocation via synthetic portfolios, protecting the value of portfolios, speculation, allowing hedging of exposure, and reducing holding and transaction costs.

Index-based property futures for housing markets have been advocated for both US housing markets (Case et al, 1993; Shiller and Weiss, 1999) and UK housing markets (Gemmill, 1990; Thomas, 1996). The London Futures and Options Exchange (FOX) introduced property futures for UK residential markets in May 1991, with futures contracts based on the Nationwide Anglia Building Society house price (NAHP) index and the FOX mortgage interest rate (MIR) index (Baum, 1991; Patel, 1994). Trading in both futures contracts was suspended in October 
1991 because of non-viable trading volumes, lag dependence in the NAHP index and the high transaction costs and long time lags in the MIR index (Patel, 1994).

More recently, a small-scale housing futures program (Home Equity Protection Program) has been established in the US (Perkins, 2003), with the City Index Property Futures established in the UK (www.cityindex.co.uk). The City Index Property Futures involve futures contracts for five UK regions, three London boroughs and a "Millionaire" index. These futures are based on the transactionbased "Residential Property Price Report" released quarterly by the UK Land Registry. Neither of the housing futures programs in the US or UK are conducted through the respective futures exchanges.

For UK commercial property, FOX also established two property futures in May 1991, based on the Investment Property Databank (IPD) capital index and the IPD rental index. Trading in these futures contracts was also suspended in October 1991 because of non-viable trading volumes and artificially supported trading volumes (Hoesli and MacGregor, 2000). In the late 1990's, Barclays PICs and Property Index Forward were also introduced, based on the IPD indices (Hoesli and MacGregor, 2000).

For US REITs, Giliberto (1993) developed a hedged REIT index. Importantly, existing futures contracts for stocks, financial/interest rates, commodities and metals have been shown to not effectively hedge REIT returns (Liang et al, 1998; Oppenheimer, 1996). This has highlighted the need for specific REIT futures contracts for effective hedging of REIT returns; with some likelihood of REIT futures being introduced in the US in 2004-05.

For Australian LPTs, Newell (1996) developed a hedged LPT index. However, the crucial development has been the establishing of a LPT futures market on the ASX in August 2002; this being a world first for this type of property investment vehicle. The following section gives details of the LPT futures market.

\section{FUTURES MARKETS IN AUSTRALIA}

\section{Sydney Futures Exchange}

The Sydney Futures Exchange (SFE) is the 10th largest futures exchange in the world and the 2nd largest in Asia, having operated for over 40 years. The SFE offers futures trading in equities, interest rates, commodities and currencies, for both Australia and New Zealand, with Table 2 detailing the specific SFE Australian futures contracts (39) currently available at December 2003 (SFE, 2003). Futures on the SFE are used by fund managers, index managers, asset allocators and arbitrageurs as effective tools for hedging, speculation, transition management and arbitrage. Their increased use in risk management has reflected the uncertainty in 
the investment environment and increased market volatility in recent years (Montgomery, 2002).

\section{Table 2: Futures on the SFE}

Equities (1): ASX 200

Currencies (1): Aust \$

Interest rates (4): 90-day bank bills

3-year bonds

10 -year bonds

30-day interbank cash rate

Commodities (4): Fine wool

Greasy wool

Broad wool

Cattle

Electricity (8): Peak period (NSW, VIC, QLD, SA)

Base load (NSW, VIC, QLD, SA)

Individual shares (21): AMP, ANZ, BHP, CBA, Fosters, NAB, News Corp, Rio Tinto, St George, Telstra, Westpac, Woolworths, etc.

Source: www.sfe.com.

In 2002, 34 million futures contracts valued at \$11 trillion were traded; this being larger than Australia's GDP and stockmarket turnover (SFE, 2003). On a daily basis, this represents a turnover of 134,000 futures contracts valued at $\$ 43$ billion. Table 3 details the turnover for specific equity, interest rates, commodities and currencies futures in 2002. The major futures products traded are 90 -day bills $(\$ 8.5$ trillion), 3-year bonds ( $\$ 1.6$ trillion), 10-year bonds ( $\$ 520$ billion) and ASX200 (\$298 billion); these representing some of the most actively traded bonds and interest rate futures products in the world. No property futures are traded on the SFE.

\section{Futures on the Australian Stock Exchange}

A futures market on the ASX was established in January 2002, with the introduction of ASX Mini Index Futures for futures trading on the ASX200 and ASX50 (ASX, 2003a). Table 4 lists the range of futures products (21) available on the ASX at December 2003. 
Table 3: Performance analysis: SFE futures: 2002

\begin{tabular}{|c|c|c|c|c|c|c|}
\hline \multirow[b]{2}{*}{ Sector } & \multicolumn{2}{|c|}{ Lots Traded } & \multicolumn{2}{|c|}{ Volume Traded } & \multicolumn{2}{|c|}{ Monthly Analysis } \\
\hline & \# & $\%$ & $\$$ & $\%$ & $\begin{array}{c}\text { Lots } \\
\text { traded }\end{array}$ & $\begin{array}{l}\text { Volume } \\
\text { traded }\end{array}$ \\
\hline 3-year bonds & $16.46 \mathrm{M}$ & $48.4 \%$ & $\$ 1.65 \mathrm{~T}$ & $15.0 \%$ & $1.37 \mathrm{M}$ & $\$ 137 \mathrm{~B}$ \\
\hline 90-day bills & $8.49 \mathrm{M}$ & $25.0 \%$ & $\$ 8.49 \mathrm{~T}$ & $77.5 \%$ & 707,213 & $\$ 707 \mathrm{~B}$ \\
\hline 10-year bonds & $5.20 \mathrm{M}$ & $15.3 \%$ & $\$ 520 B$ & $4.7 \%$ & 433,358 & $\$ 43 \mathrm{~B}$ \\
\hline ASX200 & $3.76 \mathrm{M}$ & $11.1 \%$ & \$298B & $2.7 \%$ & 313,492 & $\$ 25 B$ \\
\hline Aust \$ & 29,076 & $0.1 \%$ & $\$ 2.9 \mathrm{~B}$ & $<0.1 \%$ & 2,423 & $\$ 242 \mathrm{M}$ \\
\hline Commodities* & 19,057 & $<0.1 \%$ & $\$ 616 \mathrm{M}$ & $<0.1 \%$ & 1,588 & $\$ 51 \mathrm{M}$ \\
\hline Electricity* & 1,151 & $<0.1 \%$ & $\$ 55 \mathrm{M}$ & $<0.1 \%$ & 96 & $\$ 5 \mathrm{M}$ \\
\hline $\begin{array}{l}\text { Individual } \\
\text { shares* }\end{array}$ & 29,286 & $0.1 \%$ & $\$ 463 \mathrm{M}$ & $<0.1 \%$ & 2,440 & $\$ 39 M$ \\
\hline Total & 33.99M & $100 \%$ & \$10.96T & $100 \%$ & $2.83 \mathrm{M}$ & \$913B \\
\hline
\end{tabular}

*: sector aggregated

Source: Authors' compilation from www.sfe.com.au

Table 4: Futures on the ASX

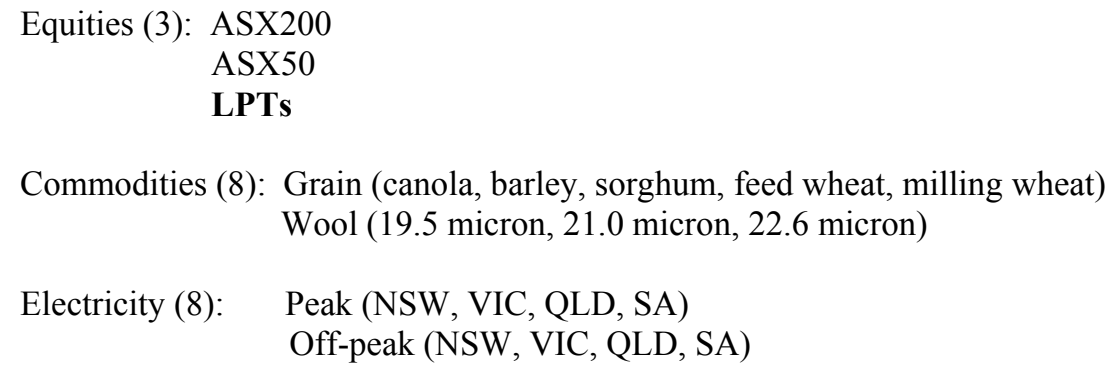

Source: www.asx.com.au/futures

Features of Mini Index futures contracts on the ASX include (ASX, 2003a):

- futures contract value of $\$ 10$ per index point

- maturity dates at 3rd Friday in March, June, September and December

- initial margins vary

- traded on ASX options and futures trading platform

- cleared through ASX futures trading house

- costs can be offset against other futures contracts

- shares can be used as collateral to cover initial margins, 
with major brokers for futures contracts including ABN Amro, JP Morgan, Macquarie and Salomon Smith Barney.

For August 2002 - November 2003, over 84,000 ASX futures contracts were traded (see Table 5), representing only $0.4 \%$ of the ASX's equity trading volume and $0.2 \%$ of the SFE's futures trading volume over this 16-month period. Whilst these ASX futures volumes are low in comparison to the SFE futures volumes, the ASX futures market provides access to property futures.

\section{Property futures on the ASX}

Property futures on the ASX were introduced in August 2002 with the ASX Mini Property Futures, with the underlying index being the ASX200 LPT index and having the benefit of the liquidity, depth and size of the LPT sector (ASX, 2003b; Montgomery, 2002).

These property futures have provided investors with an effective LPT risk management tool for hedging of LPT exposure, better management of cash flows, facilitating tactical asset allocation and enhanced leverage. In 2003, specific property futures contracts were:

- XPJ3H: maturing March 2003

- XPJ3U: maturing September 2003
- XPJ3M: maturing June 2003

- XPJ3Z: maturing December 2003.

Table 5: Performance analysis: ASX futures: Aug 2002 - Nov 2003

\begin{tabular}{|c|c|c|c|c|c|c|}
\hline \multirow[b]{2}{*}{ Sector } & \multicolumn{2}{|c|}{ Lots Traded } & \multicolumn{2}{|c|}{ Volume Traded } & \multicolumn{2}{|c|}{ Monthly Analysis } \\
\hline & \# & $\%$ & $\$$ & $\%$ & $\begin{array}{l}\text { Lots } \\
\text { traded }\end{array}$ & $\begin{array}{l}\text { Volume } \\
\text { traded }\end{array}$ \\
\hline LPTs & 41,958 & $49.7 \%$ & $\$ 526.1 \mathrm{M}$ & $32.0 \%$ & 2,622 & $\$ 32.9 \mathrm{M}$ \\
\hline ASX200 & 23,857 & $28.3 \%$ & $\$ 724.5 \mathrm{M}$ & $44.0 \%$ & 1,491 & $\$ 45.3 \mathrm{M}$ \\
\hline ASX50 & 6,716 & $8.0 \%$ & $\$ 307.4 \mathrm{M}$ & $18.7 \%$ & 420 & $\$ 19.2 \mathrm{M}$ \\
\hline Grain* & 11,429 & $13.5 \%$ & $\$ 45.4 \mathrm{M}$ & $2.8 \%$ & 714 & $\$ 2.8 \mathrm{M}$ \\
\hline Electricity* & 370 & $0.4 \%$ & $\$ 40.8 \mathrm{M}$ & $2.5 \%$ & 23 & $\$ 2.6 \mathrm{M}$ \\
\hline Wool* & 53 & $0.1 \%$ & $\$ 1.2 \mathrm{M}$ & $0.1 \%$ & 3 & $\$ 0.1 \mathrm{M}$ \\
\hline Total & 84,383 & $100 \%$ & $\$ 1,645.4 M$ & $100 \%$ & 5,274 & $\$ 102.8 M$ \\
\hline
\end{tabular}

*: sector aggregated

Source: Authors' compilation from www.asx.com.au/futures 
Table 5 shows the contribution by each of the ASX futures sectors to ASX futures trading over August 2002 - November $2003^{(1)}$. At nearly 42,000 contracts, LPT futures accounted for nearly $50 \%$ of all ASX futures contracts, well ahead of the benchmark ASX200 futures with 23,857 contracts (28.3\%). At \$526 million, LPT futures accounted for $32.0 \%$ of the value of all ASX futures contracts over this period. Given the significant contribution by property futures to the ASX futures market, the following sections give fuller details of the performance of ASX property futures.

\section{METHODOLOGY}

Daily property futures closing price, LPT index and property futures trading volume statistics were obtained from the Australian Financial Review for the following three property futures contracts:

- XPJ3M: maturing June 2003

- XPJ3U: maturing September 2003

- XPJ3Z: maturing December 2003,

as well as for the corresponding ASX200 futures and the other ASX futures. This resulted in trading activity data being available for 193 days over the period of 1 April 2003 - 19 December 2003.

To assess the effectiveness of property futures as a LPT portfolio risk management tool, a number of property futures contract scenarios were examined, involving both unexpected shocks and structural change in the LPT sector. These scenarios involved:

- unexpected shock: impact of commencement of Iraq War (March 2003)

- structural change: impact of reduced LPT attractiveness, increasing bond rates, shift from defensive stocks to general equities sector with improving stockmarket (June 2003).

\section{RESULTS AND DISCUSSION}

\section{Property futures performance}

With the ASX200 LPT index being the underlying index for property futures, Figure 1 presents the LPT price index and LPT trading volume over December 2002 - December 2003. Significant LPT trading volume in March largely reflects merger and acquisition activity lead by some of the major LPTs, particularly Centro, Westfield and Stockland. Significant trading activity in June reflected a reduction in LPT attractiveness, as institutions shifted from defensive stocks to the

${ }^{1}$ August 2002 was chosen as start date for analysis of ASX futures sectors as it coincided with introduction of ASX property futures. 
general equities sector with an improving stockmarket; this was coupled with increasing bond rates. This saw a general decline in LPT performance over June November 2003, giving a return of $-2.6 \%$ for LPTs for the six months to November 2003 , compared to a return of $9.8 \%$ for the overall stockmarket over this same period (UBS Warburg, 2003).

Figure 1: LPT performance and LPT trading volume: 2003

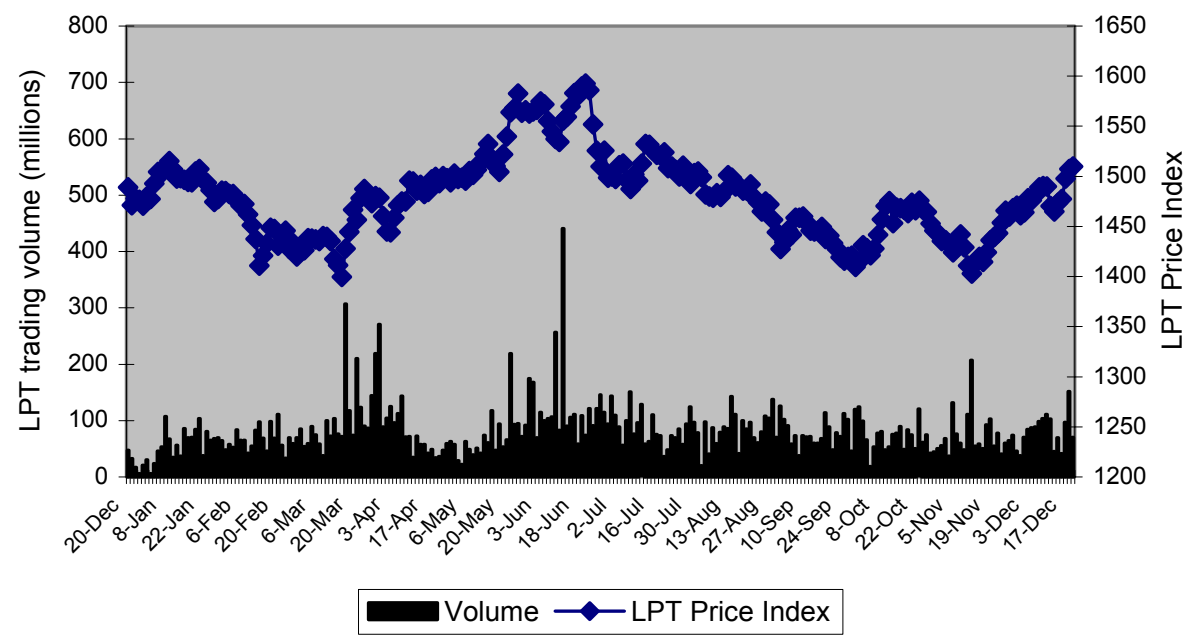

Figure 2 presents the property futures closing price, property futures trading volume and LPT index over March-December 2003. Significant property futures trading volume is evident over late June-early July, coinciding with the reduced LPT attractiveness and increasing bond rates. Other periods of high trading volume also coincided with drops in the LPT index; eg: April, May, August, September, October and December.

The correlation between the property futures closing price and the LPT index was .986 , while the correlation between the percentage changes in the property futures closing price and the LPT index was .750. Whilst not being statistically significant $(\mathrm{P}<5 \%)$, the correlation between the percentage change in the LPT index and property futures trading volume was -.107 , reflecting some degree of futures trading responses to declines in the LPT index. Non-synchronous trading activity is also reflected to some degree in the negative lagged correlations between the percentage change in the LPT index and property futures trading volume; eg: -.047 (lag of 1 day), -.125 (lag of 3 days) and -.156 (lag of 5 days).

Based on the 193 days of property futures trading over 1 April - 19 December 2003, Table 6 compares the trading activity of property futures compared to the 
other available ASX futures; particularly the ASX200 futures. Property futures were traded more frequently (62.7\% of days) than ASX200 futures ( $24.9 \%$ of days), with contract lot sizes for property futures (179 futures contracts per lot) being larger than for ASX200 futures (130 futures contracts per lot). The trading volume for property futures at least matched the trading volume of ASX200 futures on $82.9 \%$ of trading days. Compared against all ASX futures sectors, property futures had the highest trading volume on $52.4 \%$ of trading days and was not in the top two most actively traded futures sectors on only $39.3 \%$ of trading days. This trading analysis confirms the strong acceptance of property futures amongst the portfolio of available ASX futures products.

Figure 2: Property futures performance and trading volume: March December 2003

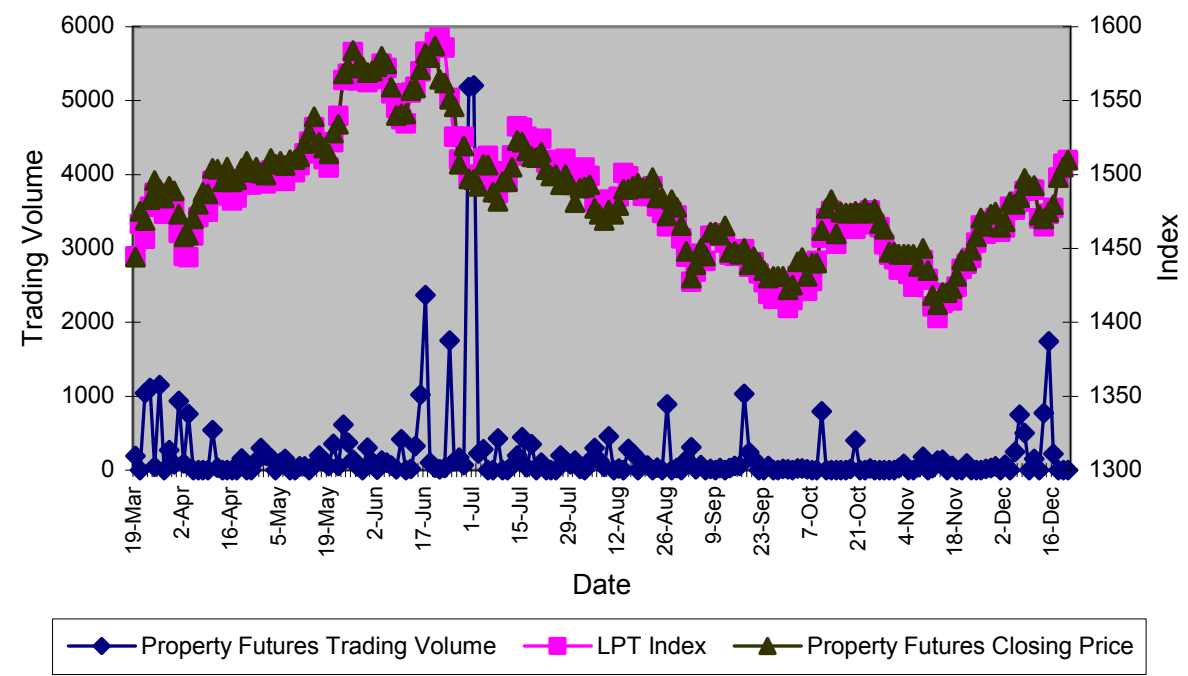

\section{Scenario analysis}

To assess the effectiveness of property futures as an LPT risk management tool, Table 7 presents three scenarios that coincided with significant LPT "events" in 2003 and its subsequent impact on a \$10 million LPT portfolio. These covered both unexpected shocks (ie: Iraq War) and structural change (ie: decline in LPT attractiveness). Whilst timing is an important issue for futures trading, these three scenarios will only consider property futures contracts to maturity.

Scenario \#1 coincides with the announcement of the Iraq War in March 2003, with 681 property futures contracts taken out to mature in June 2003. Given the defensive characteristics of LPTs in periods of uncertainty or volatility, this was not an effective LPT risk management strategy. The use of property futures saw a $1.1 \%$ 
profit on the $\$ 10$ million LPT portfolio compared to a 9.1\% profit without the use of property futures.

Table 6: LPT futures market analysis: March-December 2003

\section{Futures contracts assessed:}

XPJ3M: 3 March - 19 June

XPJ3U: 16 June - 19 September

XPJ3Z: 16 September - 19 December

\section{"Average" contract size:}

LPT: 179 contract lots at $\$ 2.7$ million

ASX200: 130 contract lots at $\$ 4.4$ million

\section{Summary of futures trading volume:}

Number of trading days: 193, covering 1 April -19 December 2003

Number of days: LPTs traded: 121 (62.7\% of days)

Number of days: ASX200 traded: 48 (24.9\% of days)

Number of days: LPT volume > ASX200 volume: 105 (54.4\% of days)

Number of days: LPT volume $=$ ASX200 volume: 55 (28.5\% of days)

Number of days: LPT volume < ASX200 volume: 33 (17.1\% of days)

Number of days: LPT $=$ highest volume of all (21) sectors: $52.4 \%$ of days

Number of days: LPT $=2$ nd highest volume of all (21) sectors: $8.3 \%$ of days

Number of days: LPT $=$ not $1 \mathrm{st} / 2$ nd highest volume of all (21) sectors: $39.3 \%$ of days

Source: Authors' compilation

Scenario \#2 uses property futures in a period of reduced LPT attractiveness in June 2003, resulting from increasing bond rates and a shift from defensive stocks with an improving stockmarket. 633 property futures contracts were taken out to mature in September 2003. In this case, the use of property futures was an effective risk management strategy, with the $9.0 \%$ loss on the $\$ 10$ million LPT portfolio offset to only a $0.3 \%$ loss by using property futures.

As a variation on scenario \#2, scenario \#3 examines the issue of market timing, with the management decision to delay the use of property futures by two weeks (until 30 June) to protect the value of the LPT portfolio. In scenario \#3, the delayed decision to use property futures sees the value of the LPT portfolio initially drop by 
$5.3 \%(\$ 533,763)$ by 30 June prior to the use of property futures. The use of property futures at 30 June then sees a further loss of only $0.4 \%$ on the initial $\$ 10$ million LPT portfolio, giving a total net loss of $5.7 \%$. This compares to a $9.0 \%$ loss $(\$ 900,133)$ without the use of property futures.

\section{Table 7: LPT futures: scenario analysis}

\begin{tabular}{|c|c|c|}
\hline \multicolumn{3}{|c|}{ Scenario \#1: 21 March - 19 June 2003} \\
\hline Date & Sharemarket & Futures market \\
\hline $21 \mathrm{March}$ & $\begin{array}{l}\text { LPT index: } 1456.6 \\
\text { LPT portfolio value: } \$ 10,000,000\end{array}$ & $\begin{array}{l}\text { LPT futures value: } 1468.8 \\
\text { Action: sell } 681 \text { LPT futures contracts } \\
\text { valued at } 681 \times 1468.8 \times \$ 10 \\
\quad=\$ 10,002,528\end{array}$ \\
\hline 19 June & $\begin{array}{l}\text { LPT index: } 1589.5 \\
\text { LPT portfolio value: } \$ 10,912,399 \\
\text { Profit on LPT portfolio value: } \$ 912 \text {, } \\
399 \text { ( } 9.1 \% \text { profit) }\end{array}$ & $\begin{array}{l}\text { LPT futures value: } 1587 \\
\text { Action: buy } 681 \text { LPT futures contracts } \\
\text { valued at } 681 \times 1587 \times \$ 10 \\
\quad=\$ 10,807,470\end{array}$ \\
\hline \multicolumn{3}{|c|}{ Net profit $=\$ \mathbf{1 0 7 , 4 5 7}(1.1 \%$ profit on LPT portfolio $)$} \\
\hline
\end{tabular}

\begin{tabular}{|c|c|c|}
\hline \multicolumn{3}{|c|}{ Scenario \#2: 17 June - 19 September 2003} \\
\hline Date & Sharemarket & Futures market \\
\hline 17 June & $\begin{array}{l}\text { LPT index: } 1583.1 \\
\text { LPT portfolio value: } \$ 10,000,000\end{array}$ & $\begin{array}{l}\text { LPT futures value: } 1582 \\
\text { Action: sell } 633 \mathrm{LPT} \text { futures contracts } \\
\text { valued at } 633 \times 1582 \times \$ 10 \\
\quad=\$ 10,014,060\end{array}$ \\
\hline 19 September & $\begin{array}{l}\text { LPT index: } 1440.60 \\
\text { LPT portfolio value: } \$ 9,099,867 \\
\text { Loss on LPT portfolio value: } \$ 900,133 \\
(9.0 \% \text { loss })\end{array}$ & $\begin{array}{l}\text { LPT futures value: } 1444.5 \\
\text { Action: buy } 633 \text { LPT futures contracts } \\
\text { valued at } 633 \times 1444.5 \times \$ 10 \\
\quad=\$ 9,143,685 \\
\text { Profit on futures value: } \$ 870,375\end{array}$ \\
\hline \multicolumn{3}{|c|}{ Net loss $=\$ 29,758(0.3 \%$ loss on LPT portfolio $)$} \\
\hline
\end{tabular}

\begin{tabular}{|c|c|c|}
\hline \multicolumn{3}{|c|}{ Scenario \#3: 17 June - 30 June - 19 September 2003} \\
\hline Date & Sharemarket & Futures market \\
\hline 17 June & $\begin{array}{l}\text { LPT index: } 1583.1 \\
\text { LPT portfolio value: } \$ 10,000,000\end{array}$ & \\
\hline 30 June & $\begin{array}{l}\text { LPT index: } 1498.6 \\
\text { LPT portfolio value: } \$ 9,466,237 \\
\text { Loss on LPT portfolio value: } \$ 533,763 \\
(5.3 \% \text { loss })\end{array}$ & $\begin{array}{l}\text { LPT futures value: } 1497 \\
\text { Action: sell } 633 \text { LPT futures contracts } \\
\text { valued at } 633 \times 1497 \times \$ 10 \\
\quad=\$ 9,476,010\end{array}$ \\
\hline 19 September & $\begin{array}{l}\text { LPT index: } 1440.60 \\
\text { LPT portfolio value: } \$ 9,099,867 \\
\text { Loss on LPT portfolio value: } \$ 900,133 \\
(9.0 \% \text { loss })\end{array}$ & $\begin{array}{l}\text { LPT futures value: } 1444.5 \\
\text { Action: buy } 633 \text { LPT futures contracts } \\
\text { valued at } 633 \times 1444.5 \times \$ 10 \\
\quad=\$ 9,143,685 \\
\text { Profit on futures value: } \$ 332,325\end{array}$ \\
\hline \multicolumn{3}{|c|}{$\begin{aligned} \text { Net loss }=\$ 567,808 & (5.7 \% \text { loss on original LPT portfolio }) \text {, comprising: } \\
& \bullet \$ 533,763(5.3 \% \text { loss from unhedged position }) \\
& \bullet \$ 34,045(0.4 \% \text { loss from hedged position })\end{aligned}$} \\
\hline
\end{tabular}

Source: Authors' compilation 
Scenarios \#2 and \#3 clearly demonstrate the effective use of property futures as an LPT risk management tool in protecting the value of the LPT portfolio in a declining LPT environment.

\section{PROPERTY IMPLICATIONS}

With the increased use of LPTs as a liquid property investment vehicle amongst Australian institutional investors, property futures provide an effective LPT risk management tool for hedging LPT exposure, as well as for speculation, transition management and arbitrage.

The experience of the sixteen months since the introduction of property futures in Australia in August 2002 has seen property futures as the most actively supported of the range of ASX futures products; particularly with property futures not being available on the more substantive Sydney Futures Exchange. Whilst liquidity is a key factor in the success of futures markets, the ongoing liquidity and depth of the underlying LPT index should be a crucial factor in its long-term success.

With more extensive property futures trading history to become available in subsequent years, this area of property futures remains a unique property research opportunity, particularly with an equivalent US REIT futures product not yet available. Future research areas include:

- Understanding the drivers for major movements between LPT futures and the LPT index

- Surveying institutional investors and fund managers to assess their usage of LPT futures in LPT portfolio risk management

- A typical property securities fund will have a small portion of its asset allocation invested in cash to meet withdrawals and additional investments. This cash drag can be minimised through cash management techniques applying property trust futures. The effectiveness and return pickup offered by this synthetic cash management strategy can be evaluated

- While property trust futures are useful in standard hedging strategies by institutional investors, the derivative product can also be applied to reduce the systematic risk of the overall property portfolio through dynamic hedging, which not only eliminates the downside risk, but also enjoys upside potential. The cost and payoff of creating a synthetic property securities portfolio with property trust futures and cash, compared to the actual LPT portfolio, is also worth exploring 
- Cross hedging can be used to reduce the risk for individual LPTs. The cross hedge ratios of each LPT and the effectiveness of cross hedging warrant future research.

\section{REFERENCES}

Australian Stock Exchange. 2003a. Futures. ASX: Sydney.

Australian Stock Exchange. 2003b. Property Trust Futures. ASX: Sydney

Baum, A. 1991. Property futures. Journal of Property Valuation and Investment 9(3): $235-240$.

Case, K., Shiller, R. and Weiss, A. 1993. Index-based futures and options markets in real estate. Journal of Portfolio Management (Winter): 83-92.

Gemmill, G. 1990. Futures trading and finance in the housing market. Journal of Property Finance 1(2): 196-207.

Giliberto, M. 1993. Measuring real estate returns: the hedged REIT index. Journal of Portfolio Management (Spring): 94-99.

Hoesli, M. and MacGregor, B. 2000. Property Investment: Principles and Practice of Portfolio Management. Longman: Harlow.

Liang, Y., Seiler, M. and Chatrath, W. 1998. Are REIT returns hedgeable? Journal of Real Estate Research 16(1): 87-97.

Montgomery, R. 2002. Listed property trust derivatives. Annual Listed Property Trust Review 2003. PIR: Melbourne.

Newell, G. 1996. A hedge around your property. Journal of Australian Society of Security Analysts (July): 28-30.

Newell, G. and Acheampong, P. 2001. The dynamics of the Australian LPT market risk and correlation profile. Pacific Rim Property Research Journal 7(4): 259-270.

Oppenheimer, P. 1996. Hedging REIT returns using futures markets. Journal of Real Estate Portfolio Management 2(1): 41-53.

Patel, K. 1994. Lessons from the FOX residential property futures and mortgage interest rate futures market. Housing Policy Debate 5(3): 343-360. 
Perkins, B. 2003. A future for housing futures? Foreclosure Point (www.foreclosurepoint.com).

Property Investment Research. 2002. Annual Listed Property Trust Review 2003. PIR: Melbourne.

Property Investment Research. 2003. Australian Property Funds Industry Survey 2003. PIR: Melbourne.

Property Council of Australia. 2003. Investment Property Index: June 2003. PCA: Sydney.

Shiller, R. and Weiss, A. 1999. Home equity insurance. Journal of Real Estate Finance and Economics 19(1): 21-47.

Sydney Futures Exchange. 2003. Introduction to futures and options. SFE: Sydney.

Thomas, R. 1996. Indemnities for long-term price risk in the UK housing market. Journal of Property Finance 7(3): 38-52.

UBS Warburg 2003. UBS Warburg indices: November 2003 (and miscellaneous copies). UBS Warburg: Sydney.

Wilson, P. and Okunev, J. 1996. Evidence of segmentation in domestic and international property markets. Journal of Property Finance 7(4): 78-97.

Wilson, P. and Okunev, J. 1999. Long-term dependencies and long-run nonperiodic co-cycles: real estate and stockmarkets. Journal of Real Estate Research 18(2): 257-278.

Wilson, P., Okunev, J. and Webb, J. 1998. Step interventions and market integration: tests in the US, UK and Australian property markets. Journal of Real Estate Finance and Economics 16(1): 91-123. 